\title{
THROMBOTIC THROMBOCYTOPENIC PURPURA FOLlOWING INFLUENZA VACCINATION: A CASE REPORT
}

\author{
Guardia Schoenfeld, Diana ${ }^{1}$; Morales Navarro, Karla ${ }^{2}$; Guzmán Cervantes, Rodolfo ${ }^{3}$ y Monge \\ Bonilla, Cecilia ${ }^{4}$ \\ 1 Médico General. San José, Costa Rica. \\ 2 Médico Residente en Anatomía Patológica, Servicio de Anatomía Patológica, Hospital San Juan de Dios y Escuela de \\ Medicina, Universidad de Costa Rica. San José, Costa Rica. \\ 3 Médico Especialista en Anatomía Patológica. Servicio de Anatomía Patológica, Hospital San Juan de Dios y Escuela de \\ Medicina, Universidad de Costa Rica. San José, Costa Rica. \\ 4 Médico Especialista en Medicina Interna. Departamento de Medicina Interna. Sección de Medicina 4. Hospital San Juan de \\ Dios. San José, Costa Rica.
}

\begin{abstract}
Resumen: La púrpura trombótica trombocitopénica (PTT) es un síndrome con alta mortalidad caracterizado por anemia hemolítica microangiopática, trombocitopenia y trombos microvasculares resultando en daño en múltiples sistemas. Presentamos el caso de un hombre de 69 años quien presentó trombocitopenia, ictericia, dolor epigástrico, síntomas abdominales difusos y alteración del estado de la conciencia, 5 días después de recibir la vacuna de la influenza. El cuadro clínico fue fulminante y llevó a su muerte antes del diagnóstico y tratamiento. La autopsia mostró el diagnóstico de PTT. La deficiencia de ADAMTS13 ha sido documentada ampliamente en la patogénesis de la PTT. Auto-anticuerpos dirigidos hacia ADAMTS13 también han sido asociados en muchos casos, pero raramente la vacuna de la influenza se ha presentado como detonante de este padecimiento.
\end{abstract}

Palabras clave: Púrpura trombótica trombocitopénica (PTT), factor von Willebrand, ADAMTS13, vacuna influenza. 
Abstract: Thrombotic thrombocytopenic purpura (TTP) is a life-threatening syndrome characterized by microangiopathic hemolytic anemia, thrombocytopenia, and microvascular thrombi resulting in damage to multiple organ systems. We present the case of a 69-year old male who presented with thrombocytopenia, jaundice, epigastric pain and altered mental status 5 days after receiving an influenza vaccination. Unfortunately, the clinical presentation was fulminant leading to death before the diagnosis of TTP and treatment with plasma exchange was done. Postmortem examination showed the diagnosis of TTP. ADAMTS13 deficiency has been well documented as involved in the pathogenesis of TTP. Autoantibodies against ADAMTS13 have also been implicated in many cases, but rarely with a trigger such as the influenza vaccination.

Key words: Thrombotic thrombocytopenic purpura (TTP), von Willebrand factor (vWF), ADAMTS13, influenza vaccination

\section{INTRODUCTION}

Thrombotic thrombocytopenic purpura (TTP) is a life-threatening syndrome characterized by microangiopathic hemolytic anemia, thrombocytopenia, and microvascular thrombi resulting in damage to multiple organ systems (1). First described in 1924 by Dr. Eli Moschowitz (2), recent knowledge of its pathophysiology and importance of prompt diagnosis and management, has drastically diminished the high mortality rate associated with TTP from $80-90 \%$ to 10 $20 \%(3)$.

A pentad of features has classically identified TTP: thrombocytopenia, microangiopathic hemolytic anemia (MAHA), renal failure, fever, and a varying degree of neurological abnormalities (4). In view that all of these criteria are rarely present, unexplained hemolytic anemia and thrombocytopenia suffice to initiate treatment (1).

We report a case of acquired TTP following influenza vaccination.

\section{CASE REPORT}

A 69 year old male presented with a 48 hour history of jaundice, epigastric pain, vomiting and altered mental status. His medical history included a cerebrovascular accident at the age of 40 with the consequence of right hemiparesia and a preauricular basocelular carcinoma treated surgically and with radiation therapy in the year 2007 . He did not take any medications. There had been no history of weight loss, recent viral illness, diarrhea, cough or previous episodes of jaundice. Five days prior to admission he was vaccinated against influenza with a commercial inactivated influenza vaccine (split virion) BP (Sanofi Pasteur MSD) as part of a routine vaccination program.

On admission to the emergency room he was disoriented, pulse 115 beats per minute, blood pressure $160 / 90 \mathrm{mmHg}$ with an oxygen saturation of $89 \%$ on room air. He was jaundiced. His abdominal exam was normal and did not reveal hepatosplenomegaly. He did not have any hematomas or haemorrhages, rash or lymphadenopathy. The rest of the physical exam was unremarkable. 
Laboratory exams and investigations performed are summarized in Table 1.

Table 1. Laboratory analysis

\section{Haematology}

\begin{tabular}{|l|l|l|}
\hline Haemoglobin & $11.5 \mathrm{~g} / \mathrm{dl}$ & $\begin{array}{l}\mathbf{( 1 2 . 5 - 1 6 . 5} \\
\text { g/dl) }\end{array}$ \\
\hline $\begin{array}{l}\text { White blood cell } \\
\text { count }\end{array}$ & $7.0 \times 10^{3}$ & $\left.\mathbf{( 5 - 1 0 \times 1 0 ~}^{3}\right)$ \\
\hline Platelets & $9000 / \mathrm{mm}^{3}$ & $\begin{array}{l}\mathbf{( 2 0 0 0 0 0 -} \\
\mathbf{4 5 0 0 0 0} \\
\mathbf{m m}^{3} \mathbf{3}\end{array}$ \\
\hline
\end{tabular}

W

Ba

\begin{tabular}{|l}
\hline $\mathbf{S}$ \\
\hline $\mathrm{S}$ \\
\hline $\mathrm{B}$ \\
\hline
\end{tabular}

\begin{tabular}{|c|c|c|c|c|c|}
\hline \multirow{3}{*}{\begin{tabular}{|l}
2 \\
\end{tabular}} & & & \multirow{2}{*}{\multicolumn{2}{|c|}{ with $4 \mathrm{~L}$}} & \multirow{3}{*}{ 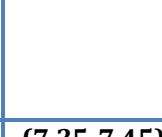 } \\
\hline & & & & & \\
\hline & & & \multirow[t]{2}{*}{ tant } & \multirow[t]{2}{*}{ 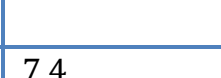 } & \\
\hline \multirow[t]{2}{*}{ Diven } & \multirow[t]{2}{*}{ 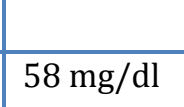 } & \multirow{2}{*}{\begin{tabular}{|l|} 
\\
$8-20$
\end{tabular}} & & & \multirow{2}{*}{ (30-41 } \\
\hline & & & $p=$ & 1.1 & \\
\hline 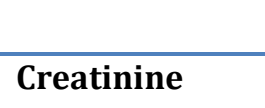 & 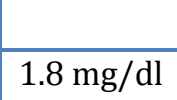 & \begin{tabular}{|l} 
(ilg/ (ii) \\
$(0.6-1.3$ \\
\end{tabular} & \multirow[t]{2}{*}{\begin{tabular}{|l} 
\\
\end{tabular}} & \multirow[t]{2}{*}{ 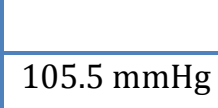 } & \multirow{2}{*}{$\begin{array}{l}\text { minig) } \\
\text { (83-108 }\end{array}$} \\
\hline \multirow[t]{2}{*}{\begin{tabular}{|l} 
\\
\end{tabular}} & \multirow[t]{2}{*}{ 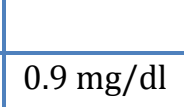 } & \multirow{2}{*}{\begin{tabular}{|l} 
ing/uij \\
$(0.1-0.5$ \\
\end{tabular}} & & & \\
\hline & & & \multirow[t]{2}{*}{\begin{tabular}{|l} 
\\
\end{tabular}} & \multirow[t]{2}{*}{ 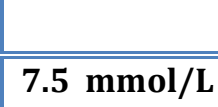 } & \multirow{2}{*}{\begin{tabular}{|l}
$121-28$ \\
$(210)$
\end{tabular}} \\
\hline \begin{tabular}{|l} 
Indirect \\
\end{tabular} & 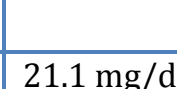 & \begin{tabular}{|l|} 
III/ai) \\
(0.5-1
\end{tabular} & & & \\
\hline
\end{tabular}

\begin{tabular}{|l|l|l|}
\hline bilirubin & $1875 \mathrm{IU} / \mathrm{L}$ & $\begin{array}{l}\mathbf{( 9 8 - 1 9 8} \\
\text { IU/L) }\end{array}$ \\
\hline $\begin{array}{l}\text { Lactate } \\
\text { dehydrogenase }\end{array}$ & $33 \mathrm{IU} / \mathrm{L}$ & $\begin{array}{l}\mathbf{( 1 7 - 6 3} \\
\text { IU/L) }\end{array}$ \\
\hline $\begin{array}{l}\text { Alanine } \\
\text { transaminase }\end{array}$ & $82 \mathrm{IU} / \mathrm{L}$ & $\mathbf{( 1 5 - 4 1 ~ I U / L )}$ \\
\hline $\begin{array}{l}\text { Aspartate } \\
\text { transaminase }\end{array}$ & $6.6 \mathrm{~g} / \mathrm{dl}$ & $\begin{array}{l}\mathbf{( 6 . 4 - 8 . 3} \\
\mathbf{g} / \text { dl) }\end{array}$ \\
\hline Protein & $3.6 \mathrm{~g} / \mathrm{dl}$ & $\mathbf{( 3 . 5 - 5} \mathrm{g} / \mathrm{dl})$ \\
\hline Albumin & $11.1 \mathrm{sec}$ & $\begin{array}{l}\mathbf{( 1 1 - 1 3 . 5} \\
\mathbf{s e c})\end{array}$ \\
\hline $\begin{array}{l}\text { Prothrombin } \\
\text { time }\end{array}$ & $25.8 \mathrm{sec}$ & $\mathbf{( 2 0 - 3 0 ~ s e c )}$ \\
\hline $\begin{array}{l}\text { Partial } \\
\text { thromboplastin } \\
\text { time }\end{array}$ & 1.03 & $\mathbf{1 - 1 . 1}$ \\
\hline INR & & \\
\hline
\end{tabular}

Revista electrónica publicada por el Departamento de Farmacología de la Escuela de Medicina de la Universidad de Costa Rica, 2060 San José, Costa Rica. ${ }^{\circledR}$ All rights reserved. Licensed under a Creative Commons Unported License. Contáctenos: rev.med.ucr@gmail.com. Tel: (506) 25-11 4492, Fax: 25-11-4489.

\begin{tabular}{|c|c|c|}
\hline \multicolumn{3}{|c|}{ Table 1 continuation } \\
\hline Urine Test & & \\
\hline Hematuria & ++++ & \\
\hline Proteinuria & +++ & \\
\hline Other Tests & & \\
\hline $\begin{array}{l}\text { Computed } \\
\text { tomography } \\
\text { scan }\end{array}$ & $\begin{array}{l}\text { Old ischemic } \\
\text { left } \\
\text { periventricular } \\
\text { lesion }\end{array}$ & \\
\hline $\begin{array}{l}\text { Abdominal } \\
\text { Ultrasound }\end{array}$ & $\begin{array}{l}\text { Reported as } \\
\text { normal }\end{array}$ & \\
\hline $\begin{array}{l}\text { Blood gases } \\
\text { with 4L nasal } \\
\text { cannula }\end{array}$ & & \\
\hline pH & 7.4 & (7.35-7.45) \\
\hline $\mathrm{pCO}_{2}$ & $12.3 \mathrm{mmHg}$ & $\begin{array}{l}\text { (30-41 } \\
\text { mmHg) }\end{array}$ \\
\hline $\mathrm{p0}_{2}$ & $105.5 \mathrm{mmHg}$ & $\begin{array}{l}\text { (83-108 } \\
\mathrm{mmHg})\end{array}$ \\
\hline $\mathrm{HCO}_{3}$ & $7.5 \mathrm{mmol} / \mathrm{L}$ & $\begin{array}{l}(21-28 \\
\mathrm{mmol} / \mathrm{L})\end{array}$ \\
\hline
\end{tabular}

There was progressive neurological worsening and 8 hours after admission to the emergency room the patient had a cardiac arrest and resuscitation maneuvers were unsuccessful.

The macroscopic autopsy findings were cardiomegaly $(380 \mathrm{~g})$ with left ventricular concentric hypertrophy $(1.9 \mathrm{~cm})$, congestive splenomegaly $(320 \mathrm{~g})$, an old left hemispheric periventricular infarction along with petechial hemorrhages in the heart (Figure 1), liver, and kidneys. Microscopic examination revealed multiple microthrombi in arterioles and capillaries of myocardium (Figure 2), glomeruli (Figure 3), portal spaces, alveolar septae, skeletal muscle, and the brain. 
Fragmented erithrocytes (schistocytes) were found in glomeruli and myocardium with accompanying myocyte necrosis (Figure 4). The heart also showed coronary atherosclerosis and diffuse myocardial fibrosis (Figure 2) as an evidence for chronic ischemic cardiopathy with a reduced myocardial reserve that together with the newly formed microthrombi lead to death in this patient. This thrombotic microangiopathy is consistent with TTP given the clinical and laboratory findings.

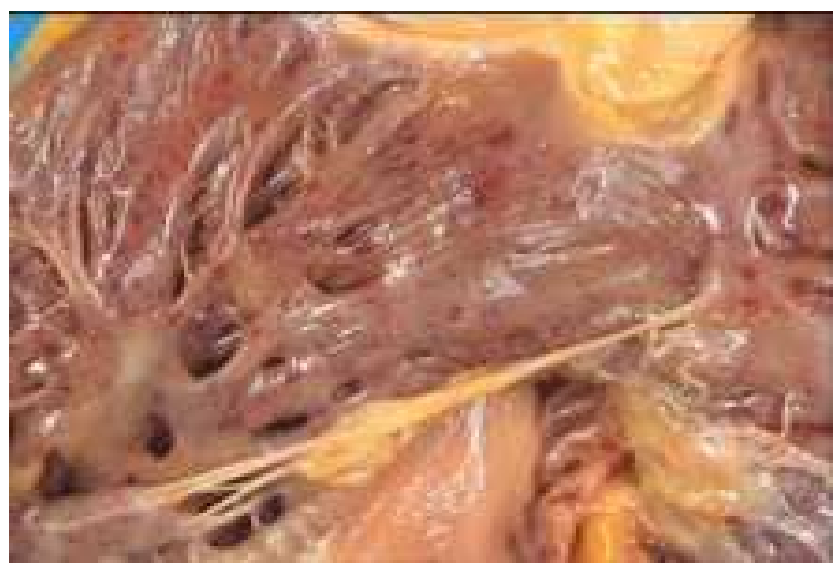

Figure 1. Petechial hemorrhages in the endocardium.

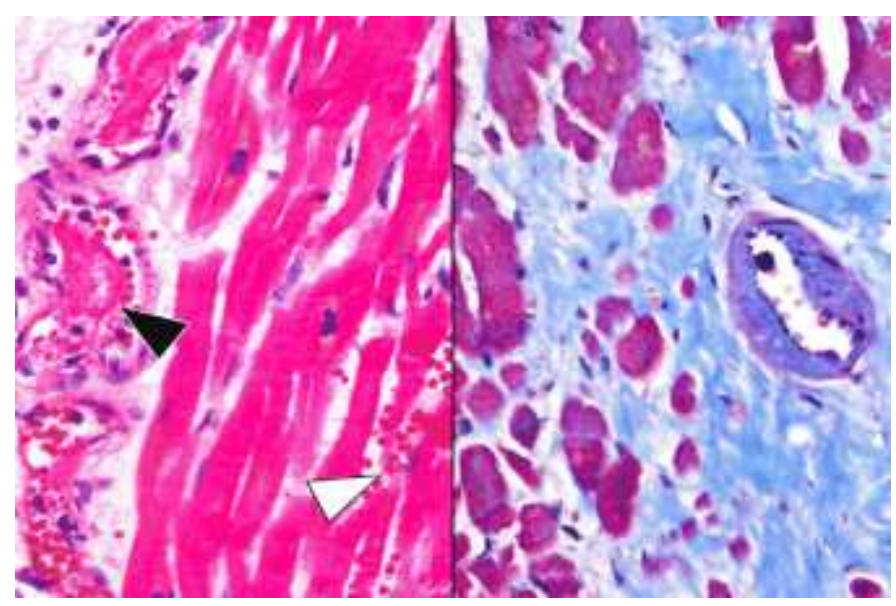

Figure 2. Left: Myocardial microthrombus (black arrowhead) and erithrocyte extravasation (white arrowhead) (Hematoxilin-Eosin, 400x). Right: Intimal and myocardial fibrosis evidenced with aniline blue (Trichrome, 400x).

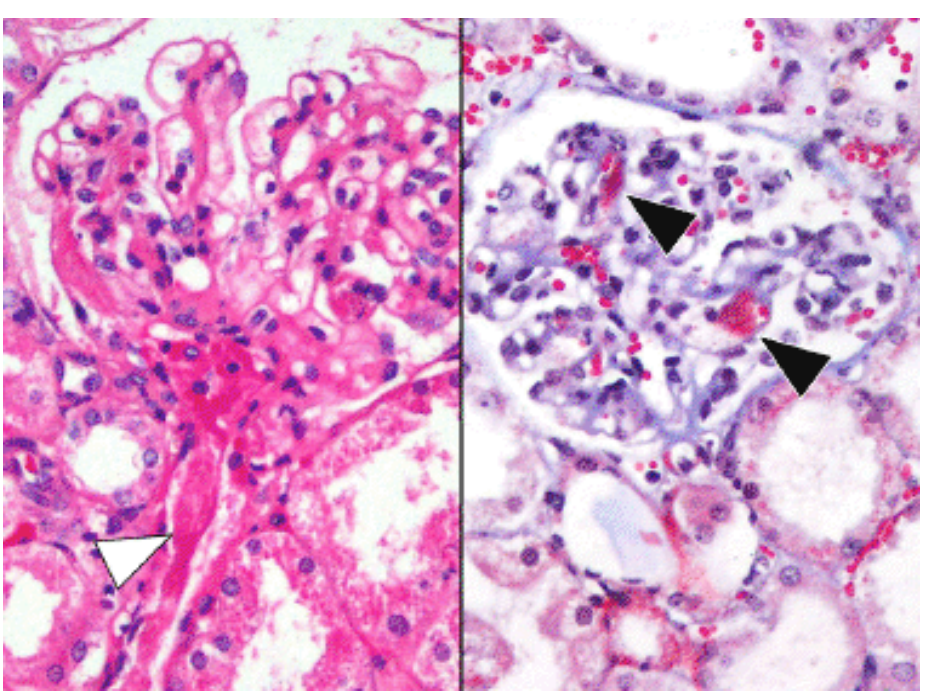

Figure 3. Left: Microthrombus in the afferent arteriole of a glomerulus (white arrowhead) (Hematoxilin-Eosin, 400x). Right: Fuchsinophilic microthrombi in the glomerular capillaries (black arrowheads) (Trichrome, 400x).

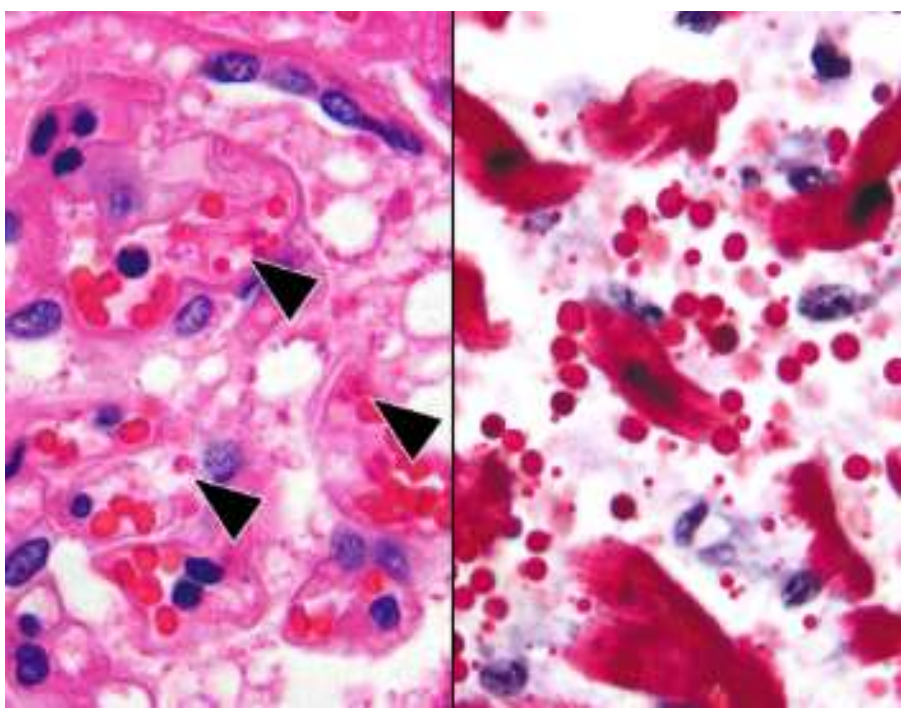

Figure 4. Left: Fragmented erithrocytes in a glomerulus (black arrowheads) (Hematoxilin-Eosin, 1000x). Right: Fragmented erithrocytes and myocardial necrosis (Trichrome, 1000x).

Revista electrónica publicada por el Departamento de Farmacología de la Escuela de Medicina de la Universidad de Costa Rica, 2060 San José, Costa Rica. ${ }^{\circledR}$ All rights reserved. Licensed under a Creative Commons Unported License. 


\section{DISCUSSION}

\section{Pathogenesis}

Thrombotic thrombocytopenic purpura (TTP) is a syndrome characterized by deposition of platelet thrombi in arterioles and capillaries (5). There are two forms of TTP: Hereditary (Upshaw-Schulman syndrome) and acquired or idiopathic TTP. Hereditary TTP is a result of a genetic mutation which leads to ADAMTS13 deficiency. Acquired TTP is usually associated with auto-antibodies to $\operatorname{ADAMTS13}(6,7)$. Pathogenesis has, therefore, been attributed to a deficiency of a von Willebrand factor (vWF) protease termed ADAMTS13 (a disintegrin-like and metalloprotease with thrombospondin type 1 motif 13 ). The role that $\mathrm{vWF}$ and its protease play in the pathogenesis of TTP has been documented since the eighties but was not made clear until 1997 and subsequently identified through genetic linkage studies in 2001(5). In congenital TTP the genetic locus is found on chromosome 9q34.

Von Willebrand factor, a large glycoprotein synthesized in vascular endothelial cells, is an important mediator in platelet adhesion and aggregation. Upon secretion into plasma, the unusually large von Willebrand factor (ULvWF) is cleaved by ADAMTS13, thereby preventing vWF from triggering additional blood clot formation. Many mutations have been identified which can cause autoantibodies (IgG) against it.

Additionally, numerous factors have been identified in patients without ADAMTS13 deficiency that have triggered acute TTP episodes. These include, but are not limited to, autoimmune diseases, infections, drugs, pregnancy, bloody diarrhea, and hematopoeitic cell transplantation, with an idiopathic cause dominating the clinical setting (8). Furthermore, TTP has also been clearly documented during acute stress in the postoperative period after cardiovascular surgery (9). Another pathogenic mechanism attributed to TTP, besides ADAMTS13 deficiency, includes fibrinolysis impairment and the impairment of other proteases capable of cleaving vWF (such as plasmin, calpain, and cathespin) (5).
Therefore, the deficiency of ADAMTS13, although a strong risk factor for developing TTP, is clearly not the only cause, and a trigger is frequently present in other idiopathic cases which ultimately leads to thrombotic microangiopathy (10).

\section{Clinical Presentation and Diagnosis}

As noted previously, an unexplained observation of hemolytic anemia and thrombocytopenia are the principal diagnostic findings that validate initiation of treatment (11). Intravascular fragmentation of red blood cells, evidenced by schistocytes in the peripheral blood smear, is a result of intravascular platelet clumping (12). High shear stress due to platelet aggregation also contributes to the variable signs and symptoms of organ ischemia and damage (5).

Laboratory results show typical findings of hemolysis, including elevated serum lactate dehydrogenase (LDH) (13), an increase in indirect bilirrubin, a reduction in haptoglobin levels, and schistocytes. This, in conjunction with thrombocytopenia, normal coagulation tests and the absence of another identifiable cause, should support the diagnosis and initiate urgent response and treatment. Other pathologies that might be considered in the differential diagnosis include: vasculitis and connective tissue diseases, hemolytic uremic syndrome, malignant hypertension, anti-phospholipid syndrome, systemic sclerosis, disseminated intravascular coagulation (DIC), malignancy, and Evans syndrome.

It is important to note that the characteristic of TTP with the resultant endothelial injury is due to platelet-rich thrombi. Therefore, the levels of the coagulation components, including prothrombin and partial thromboplastin times, are usually within normal limits. This distinction is clearly relevant with another similar entity, as is diffuse intravascular coagulation (14).

Urinalysis usually shows proteinuria and hematuria, but its degree can vary greatly among patients.

Revista electrónica publicada por el Departamento de Farmacología de la Escuela de Medicina de la Universidad de Costa Rica, 2060 San José, Costa Rica. ${ }^{\circledR}$ All rights reserved. Licensed under a Creative Commons Unported License. 
Neurological abnormalities vary from mild symptoms such as headache and confusion to severe manifestations as in seizures, including coma (15).

Fever is rarely encountered in patients with TTP.

Vague abdominal symptoms may also be present, including epigastric pain, nausea, vomiting, and diarrhea.

Cardiac involvement is associated with a higher morbidity and mortality rate in patients who developed TTP (16). Complications such as arrhythmia, sudden cardiac death, myocardial infarction, cardiogenic shock, and heart failure are a direct consequence of platelet thrombi, ischemia, and necrosis in cardiac tissue.

\section{Treatment}

Treatment is based on the underlying pathogenesis of TTP. The standard treatment for TTP has been established as plasma exchange with fresh frozen plasma. Plasmapheresis is variable within patients, but platelet count and serum lactate dehydrogenase (LDH) levels have been used as parameters to determine duration of treatment and remission. A recent study suggested that LDH may not be such a reliable marker since its serum levels are also affected by other secondary processes (12). LDH response was also determined to lag behind platelet recovery once treatment had begun. The additional use of corticosteroids (methylprednisolone 100mg IV every $12 \mathrm{hr}$ ) also improved survival rate; duration depended on the attending physician. In cases of refractory or relapsing TTP, the addition of rituximab, azathioprine, or vincristine as an adjunct treatment has also been reported (12).

Rituximab is a chimeric monoclonal antibody directed against CD20. Initially used in the treatment of non-Hodgkin lymphoma and chronic lymphocytic leukemia, additional uses have also successfully been documented in refractory cases of rheumatoid arthritis and autoimmune hematological diseases such as TTP. Its mechanism is not only attributed to B cell depletion but blockage of macrophage Fc-receptor function, thereby reducing platelet sequestration in the spleen (17). Although rituximab therapy has been established as safe, caution should be taken due to some reports of life-threatening adverse effects, including hepatitis B reactivation and its related complications, progressive multifocal leukoencephalopathy (PML), neutropenia, intestinal perforation and obstruction, and delayed interstitial pneumonitis (18). Most cases have been reported in immunosupressed patients with lymphoma (17). HIV patients are also more susceptible to undesirable effects. Recommendation of checking HIV and hepatitis B status in all patients before its utilization is a reasonable precaution. Other anti-CD20 monoclonal antibodies have surfaced but are still in clinical trials, including ofatumumab, ocrelizumab, and veltuzumab.

As of now, the use of rituximab as adjunctive therapy seems to offer a therapeutic benefit to patients with relapsing TTP. The majority of patients with TTP have received the same standard dose as patients with non-Hodgkin lymphoma, $375 \mathrm{mg} / \mathrm{m} 2$ once a week for a total of four weeks. Recent reports have shown positive outcomes with lower doses in immune mediated disorders(18). Long term follow up of nine patients with idiopathic TTP refractory to plasma exchange treated with rituximab documented no side effects (19).

Another promising adjunct treatment that has also been suggested is that of recombinant ADAMTS13, but further investigation is still needed (20).

\section{CONCLUSIONS}

Preventive medicine is an essential step in the reduction of morbidity and mortality. Although recently a wide range of autoimmune diseases have surfaced as a consequence of immunization (21), rarely has vaccination been associated with TTP. ADAMTS13 deficiency due to either a hereditary or idiopathic cause has been clearly documented in the pathogenesis of TTP. In this case the influenza vaccination seems to have served as a trigger for the acute TTP episode encountered. Interestingly, this patient also had a 
previous thrombotic event at the age of 40 . Unfortunately, testing for presence of auto-antibodies to ADAMTS13 or ADAMTS13 deficiency was not available in this case. Crucial in this life-threatening syndrome is prompt diagnosis and treatment. Therefore, microangiopathic hemolytic anemia associated with thrombocytopenia should strongly urge diagnosis of TTP with initiation of plasma exchange.

\section{REFERENCES}

1. Kempton CL. Chapter 93: Thrombotic Thrombocytopenic Purpura. In: Transfusion Medicine and Hemostasis, Clinical and Laboratory Aspects. Academic Press 2009. pp509-512.

2. Moschowitz E. Hyaline thrombosis of the terminal arterioles and capillaries: a hitherto undescribed disease. Proc N Y Pathol Soc 1924;24:21-24.

3. Verbeke L, Delforge M, Dierickx D. Current insight into thrombotic thrombocytopenic purpura. Blood Coagul Fibrinolysis 2010 Jan;21(1):3-10.

4. Kosugi $\mathrm{N}$, Tsurutani $\mathrm{Y}$, Isonishi $\mathrm{A}$, Hori $\mathrm{Y}$, Matsumoto M, Fujimura Y. Influenza A Infection Triggers Thrombotic Thrombocytopenic Purpura by Producing the Anti-ADAMTS13 IgG Inhibitor. Internal Medicine 2010;49:689-693.

5. Lian EC-Y. Pathogenesis of Thrombotic Thrombocytopenic Purpura: ADAMTS13 Deficiency and Beyond. Seminars in Thrombosis and Hemostasis 2005;31(6):625-632.

6. Lammle B, Kremer Hovinga JA, Alberio L. Thrombotic thrombocytopenic purpura. J Thromb Haemost 2005;3:1663.75.

7. Dias PJ, Gopal S. Refractory thrombotic thrombocytopenia purpura following influenza vaccination. Anaesthesia 2009;64:444-447.

8. Sadler JE. Von Willebrand factor, ADAMTS13, and thrombotic thrombocytopenic purpura. Blood 2008;112:11-18.

9. Saltzman DJ, Chang JC, Jimenez JC, Carson JG, Abolhoda A, Newman RS, Milliken JC. Postoperative thrombotic thrombocytopenic purpura after open heart operations. Annals of Thoracic Surgery 2010;89(1):119-123.
10. Furlan M, Lammle B. Aetiology and pathogenesis of thrombotic thrombocytopenic purpura and haemolytic uraemic syndrome: the role of von Willebrand factor-cleaving protease. Best Practice and Research Clinical Haemotology 2001;14(2):437454.

11. George, JN. Evaluation and management of patients with thrombotic thrombocytopenic purpura. Journal of Intensive Care Medicine 2007;22(2)82-91.

12. Zhan H, Streiff MB, King KE, Segal JB. Thrombotic thrombocytopenic purpura at the Johns Hopkins Hospital from 1192-2008: clinical outcomes and risk factors for relapse. Transfusion 2010;50:868-874.

13. Cohen JA, Brecher ME, Bandarenko N. Cellular source of serum lactate dehydrogenase elevation in patients with thrombotic thrombocytopenic purpura. J Clin Apher 1998;13:16.

14. Marder VJ, Martin SE, Francis CW, Colman RW. Consumptive thrombo-hemorrhagic disorders. In: Hemostasis and Thrombosis: Basic Principles and Clinical Practice, $2^{\text {nd }}$ ed, Lippincott, Philadelphia 1987. p.975.

15. Scully M, Yarranton H, Liesner R, et al. Regional UK TTP registry: correlation with laboratory ADAMTS13 analysis and clinical features. $\mathrm{Br} \mathrm{J}$ Haematol 2008;142:819.

16. Patschan D, Witzke O, Duhrsen U, et al. Acute myocardial infarction in thrombotic microangiopathies-clinical characteristics, risk factors and outcome. Nephro Dial Transplant 2006;21:1549.

17. Barcellini W, Zanella A. Rituximab therapy for autoimmune haematological diseases. European Journal of Internal Medicine 2011;22:220-229.

18. Dierickx D, Delannoy A, Saja K, Verhoef G, Provan D. Anti-CD20 monoclonal antibodies and their use in adult autoimmune hematological disorders. Critical Review. American Journal of Hematology 2010:278289.

19. Chemnitz JM, Uener J, Hallek M, Scheid C. Long-term follow-up of idiopathic thrombotic thromcytopenic purpura treated with rituximab. Annals of Hematology 2010;89(10):1029-1033.

20. Plaimauer B, Kremer Hovinga JA, Juno C et al. Recombinant ADAMTS13 normalizes von Willebrand factor-cleaving activity in plasma of acquired TTP patients by overriding inhibitory antibodies. Journal of Thrombosis and Haemostasis 2011;9(5):936-944.

Revista electrónica publicada por el Departamento de Farmacología de la Escuela de Medicina de la Universidad de Costa Rica, 2060 San José, Costa Rica. ${ }^{\circledR}$ All rights reserved. Licensed under a Creative Commons Unported License. 
21. Tishler, M, Levy 0 , Amit-Vazina M. Immune Thrombocytopenic Purpura Following Influenza Vaccination. IMAJ 2006;8:322-323.

\section{INFORMACION DE AUTORES:}

Guardia Schoenfeld, Diana dguard01@gmail.com

Morales Navarro, Karla

lalimo@gmail.com

Guzmán Cervantes, Rodolfo

rodolfo.guzman@ucr.ac.cr

Monge Bonilla, Cecilia

ceciliamonge4@yahoo.com 